\title{
Influence of Information Strategies on Organizational Performance for Sustainable Competitive Advantage
}

\author{
Ariyapperuma, A.R.M.I. ${ }^{1 *}$ and Nalin Abeysekera ${ }^{2}$ \\ ${ }^{1}$ Department of Business Management, Wayamba University of Sri Lanka \\ ${ }^{2}$ Department of Marketing, Open University of Sri Lanka
}

\begin{abstract}
Given the recent developments in information and communication technology business organizations adopt various strategies to enhance organizational performance. Among those strategies information strategies play a significant role. The concept of information strategies will include long-term plans designed to achieve the organizational objectives in the management of knowledge, information or data while ensuring efficiency and flexibility and ultimately leading to organizational performance. This concept paper examines the effect of information strategies on organizational performance which explores some specific strategies which can be considered as important to achieve sustainable competitive advantage for business. The concept of sustainability will focus on meeting the needs of the present without compromising the ability of future generations to meet their needs, viewed in terms of three pillars profits, planet and people; while competitive advantage will emphasize on the ability of an entity to be better off from among its competitors. Therefore, this concept paper examines the use of some specific information strategies for organizational performance with the objective of achieving sustainable competitive advantage.
\end{abstract}

Keywords: Information strategies, organizational performance, sustainable competitive advantage

\section{Introduction}

Sri Lanka is a country which is highly exposed to various developments in the global market from time to time. Such developments will mainly include economic, social, political and technological. Being a developing country the economy of Sri Lanka is experiencing frequent fluctuations given the political instability and changes in policy decision making.

When analyzing the Gross Domestic Production (GDP), Sri Lanka showed a growth of 3.2\% for the year 2018. This was 0.2\% decline compared to 2017, which was 3.4\% (Source: Central Bank of Sri Lanka (CBSL) report, 2018).

Out of the total Gross Value Added (GVA) of $90.8 \%$ in 2018 was consisted with $7.0 \%$ for agriculture, $26.1 \%$ for industry and $57.7 \%$ for services. Thereby, it shows service sector in Sri Lanka occupies a prominent position in the economy by being the highest contributor to the GDP.

It should be noted that the entities into financial services and wholesale retail trade have been the main drivers for such highest contribution in the service sector of the economy.

This makes an implication that those entities have been able to achieve a competitive advantage compared to other entities operating in the services sector. However, sustainability of such advantage will be questionable given the future performance of those organizations.

If we consider information and communication (ICT) activities of the services sector in Sri Lanka, it has grown by $8.9 \%$ in 2018 . This has been mainly due to telecommunication activities. The internet services also expanded 
rapidly due to increasing demand for data. Furthermore, information technology (IT) programming consultancy and related activities grew by $10.8 \%$ in 2018 compared to $4.2 \%$ growth in 2017.

When considering the Asian region, according to a study done by Japan International Cooperation Agency (JICA) in 2007/2008, Bangladesh was ranked first in software and IT services competitiveness and third in competencies, after India and China.

The ICT sector of Bangladesh has maintained 57.21\% growth on an average over the last nine years since 2009 . It has created around 300,000 job opportunities so far (Latifee et al, 2018). Furthermore, government of Bangladesh expects the IT sector to add 7.28\% GDP growth by 2021 (Bangladesh Sangbad Sangstha, 2013).

According to analysis reports of National Association of Software and Service Companies (NASSCOM), the percentage share of IT sector in India's GDP increased from 6.4\% (2010/2011) to 9.3\% (2015/2016), indicating a significant growth over a five (05) year period.

Therefore, it has been very much important to understand how organizational performance being influenced by IT, that will have an impact on achieving sustainable competitive advantage for those entities. However, the researcher has focused on information strategies in this regard.

\section{Research problem}

The influence of information strategies on organizational performance relating to some specific strategies which can be considered as important to achieve sustainable competitive advantage for business.

\section{Research objectives}

1. To study the concept of information strategies and its implications on the business scenario.

2. To study the theoretical relationship between information strategies and organizational performance.

\section{Literature review}

\section{Information strategies}

According to (Earl, 1989) information strategies are identified as three frameworks which were developed as a result of technology-strategy connection. This recognizes the possibility of exploiting IT to gain strategic advantage. There are two dimensions for technology-strategy connection as follows;

1. IT can support business strategy

2. IT can create strategic options

However, due to scale, sectoral or temporal differences two further dimensions introduced to technologystrategy connection;

3. IT architecture becoming a strategic concern

4. Management of information resources becomes a strategic matter

The above four (04) dimensions laid the foundation for three (03) levels of strategy in IT, identified as information strategies as follows;

1. Information systems strategy

2. Information technology strategy

3. Information management strategy
(IS strategy)

(IT strategy)

(IM strategy) 


\section{Information systems strategy (IS Strategy)}

IS strategy will identify what needs to be done with technology. Aligning IS development with business needs and seeking strategic advantage from IT. Typically formulated at the level of the strategic business unit (SBU). Corporate IS strategy concentrates on group application needs and determine IS which bring synergy to the whole corporation (Earl, 1989).

According to (Sabherwal and Chan, 2001) there are two types of IS strategy: IS for efficiency and IS for flexibility.

IS for efficiency refers to a strategy that is oriented toward operational support of intra- and inter-organizational efficiencies. For example, a firm that adopts applications for transactional and operational support (e.g. enterprise resource planning applications), for monitoring, controlling and facilitating day-to-day transactions has an IS for efficiency IS strategy.

IS for flexibility refers to a strategy that is focused on market flexibility and quick strategic decision support through applications that support strategic decision making and provide market information (Belardo et al., 1994; Sabherwal and Chan, 2001).

\section{Information technology strategy (IT Strategy)}

IT strategy will identify how do we do with technology. Concerned primarily with technology policies. Examples such as technical standards, vendor policies can be stated in this regard. Provides the framework within which the specialists provide applications and users use them (Earl, 1989).

According to (Powell and Micallef, 1997) the objective of IT strategy is to establish a mid- to long-term plan for introducing ISs and to coordinate relevant IT investments. Plans describe information resources, human resources, organizational management, and topics relevant to the introduction of ISs.

(Murakami, 1997) argued that investing in IT is widely regarded as having enormous potential for reducing costs, enhancing productivity, and improving living standards .

It can be seen from investigations performed by researchers that many enterprises developed solid plans for IT strategy, but were unable to implement them, which led to poor overall organizational performance (Bharadwaj, 2000; Peppard and Ward, 2004; Ravichandran and Lertwongsatien, 2005).

\section{Information management strategy (IM Strategy)}

IM strategy will involve management into IT. Concerned with management controls for IT, management responsibilities, performance measurement and management processes. Therefore, IM strategies operate at the corporate level of the organization (Earl, 1989).

According to (Reponen, 1994) IM strategy is a long-term precept for directing, implementing and supervising information management. It consists of following elements:

- External opportunities for using IT as a competitive weapon,

- Internal opportunities for supporting competitiveness by means of IT,

- Other application areas of IT,

- Organizing the information management function,

- A rough architecture of information technology, 
- An estimation of the IT capacity needs and investments,

- An estimation of the benefits of strategy realization.

\section{Organizational performance}

There are various definitions and interpretations introduced by researchers and scholars to understand the concept of organizational performance.

According to (Cherrington, 1989) organizational performance is a concept of success or effectiveness of an organization, and as an indication of the organizational manner that it is performing effectively to achieve its objectives successfully.

(Prakash et al, 2017) argued that organizational performance is an indicator which measures how well an organization accomplishes its objectives.

It can be measured in terms of both financial and non-financial indicators.

Financial indicators will involve ratio analysis measuring organizational performance relating to its profitability, liquidity, gearing, earnings and working capital.

Non-financial indicators are further categorized into quantitative and qualitative measures. Few of the quantitative measures will include Value Chain (VC) introduced by Michael Porter in 1985, Activity Based Costing (ABC) by Cooper and Kaplan in 1987, Balance Scorecard (BSC) by David Norton and Robert Kaplan in 1992; while qualitative will include Total Quality Management (TQM) introduced by Walter A. Shewhart in 1920, Just-in-Time (JIT) developed by Taiichi Ohno in 1970, Six Sigma by Bill Smith in 1986, Kaizan by Masaaki Imai in 1986.

From among the non-financial indicators, BSC introduced by (Norton \& Kaplan, 1992) is a combination of both financial and non-financial perspectives; whereby financial perspective will measure performance in terms of cash flow, sales growth, operating income, market share and return on equity (ROE), while non-financial perspectives will include internal business process, learning and growth and customer.

According to (Peterson et al, 2003) organizational performance is the capability and ability of an organization to efficiently utilize the available resources to achieve accomplishments consistent with the set objectives of the company, as well as considering their relevance to its users. This makes a fair opening to the concept of sustainability which will be discussed under the concept of sustainable competitive advantage.

\section{Sustainable competitive advantage}

According to (Brundtland, 1987) the term sustainability is defined as meeting the needs of the present without compromising the ability of future generations to meet their needs. Furthermore (Redclift, 1992) viewed this concept relating to three interlocking goals such as environmental, economic and social.

According to (Porter, 1985) competitive advantage will emphasize on the ability of an entity to be better-off from among its competitors. This will be mainly due to a particular strategy implemented by a firm, which will not be duplicated by rest of the other firms operating in the industry.

Those strategies are identified as being the lowest cost producer in the industry (Cost Leadership Strategy), delivering a completely unique product/ service (Differentiation Strategy) and catering to a particular market/ target or nich (Focus Strategy). Focus strategy can be further implemented as either cost focus or differentiation focus depending the on the nature of the target market. 
Therefore, the concept of sustainable competitive advantage can be defined as the capability of an organization to retain its position of being better-off from among its competitors for a foreseeable future.

However, the sustainability of the competitive advantage obtained by a firm will be eroded by the innovation efforts of rival firms changing the marketspace (Tushman and O'Reilly, 2004; Kim and Mauborgne, 2005).

\section{Discussion}

Based on the literature survey conducted the researcher has been able to introduce the concepts of information strategies and organizational performance. It was also evident that there is a relationship between information strategies and organizational performance, whereby those strategies tend to influence on the performance of the organizations, provided the management of those organizations being able to identify what needs to be done with the technology (IS strategy), how to deal with technology (IT strategy) and involve management into strategy (IM strategy). Thereby, enhancing the ability of an entity to be better-off from among its competitors, while meeting the needs of the present without compromising the ability of future generations to meet their needs.

When looking at the managerial implications, information strategies will assist organizations to optimize its limited resources in a manner that it will ensure in sustainable competitive advantage. This happens when information systems developed and implemented for business operations tend to allocate resources in accordance with respective functional requirements, ensuring optimal resource distribution; and thereby reducing resource wastages. As a result of that it will increase productivity and efficiency of business operations; thereby influencing on the organizational performance.

However, as previously stated the sustainable competitive advantage will tend to get diminished due to innovative efforts taken by rival firms. Therefore, it makes an implication that information strategies are very much important for an organization to respond to those innovative efforts of the rival firms, with the objective of retaining the competitive advantages if any obtained for a foreseeable future.

As part of further studies, this research can be expanded into various dimensions of organizational performance such as operations, marketing, finance and human resources. Furthermore, various responses taken by organizations to deal with its rivals with the objective of retaining sustainable competitive advantage can also be studied in this regard.

\section{References}

Belardo, S., Duchessi, P. \& Coleman, J.R., 1994, A strategic decision support system at Orell Fussli. Journal of Management Information Systems, 10(4), 135-57.

Bharadwaj, A., 2000, A resource-based perspective on information technology and firm performance: an empirical investigation. MIS Quarterly, 24(1), 169-96.

Brundtland, G.H., 1987, World commission on environment and development, Our Common Future (UK, Oxford University Press).

CBSL report, 2018, National output, expenditure and income, 47-85.

Cherrington, D.J., 1989, Organizational behavior: The management of individual and organizational performance (Allyn and Bacon).

Earl, M.J., 1989, Management Strategies for Information Technology (London, U.K..: Prentice-Hall).

Kaplan, R.S. \& Norton, D.P., 1992, The balanced scorecard - measures that drive performance. Harvard Business Review, Jan.-Feb., 71-79.

Karim, H.N., 2010, Bangladesh IT industry going global. The Daily Star, 06 January. 
Latifee \& Hossain, Hafiz, E., Sajib, Md., 2018, ICT industry thriving, needs reform. The Financial Express, 14 March.

Murakami, T., 1997, The Impact of ICT on Economic Growth and Productivity, Nomura Research Institute Ltd.

NASSCOM, The IT-BPM Sector in India: Strategic Review, 2015.

Peterson, W., Gijsbers, G. \& Wilks, M., 2003, An organizational performance assessment system for agricultural research organizations: concepts, methods, and procedures. ISNAR Research Management Guidelines, 7.

Porter, M.E., 1985, Competitive Advantage: Creating and Sustaining Superior Performance (New York, Free Press).

Powell, T.C. \& Micallef, A.D., 1997, Information technology as competitive advantage: the role of human, business, and technology resources. Strategic Management Journal, 18(5), 375-405.

Prakash, A., Jha, S.K., Prasad, K.D. \& Singh, A.K., 2017, Productivity, quality and business performance: an empirical study. International Journal of Productivity and Performance Management, 66(1), 78-91.

Redclift, M., 1992, Sustainable development and global environmental change: Implications of a changing agenda, Global Environmental Change, 2, 32.

Sabherwal, R. \& Chan, Y.E., 2001, Alignment between business and IS strategies: a study of prospectors, analyzers, and defenders. Information Systems Research, 12(1), 11-33.

Tushman, M. \& O’Reilly, C., 2004, The ambidextrous organization, Harvard Business Review, April, 74-81. 